\title{
The Teleos and the Anatomy of the Rule of Law in EU Infringement Procedures
}

\section{Anna Śledzińska-Simon ${ }^{1} \cdot$ Petra Bárd $^{2}$}

Published online: 5 November 2019

(c) The Author(s) 2019

\begin{abstract}
The article proves a long-lasting legacy of Martin Krygier's work on the rule of law. Taking the European Union as a case study, and specifically-the recent infringement action concerning the judicial independence in Poland, the article addresses the point (teleos) of the rule of law, the conditions the institutions need to fulfill to make this point, and institutional measures that help to meet these conditions in the EU as a whole and its Member States. It argues that the rule of law can be achieved via various paths, but there is general agreement on when its basic elements such as the guarantees against arbitrary removal of judges are missing. Therefore, it concludes, the EU does not need to determine the anatomy of national institutions, but it needs to remain vigilant against such modifications that put at risk the effectiveness of EU law, and the judicial protection of individual rights in particular.
\end{abstract}

\section{Introduction}

The illuminating work of Martin Krygier on the legality, teleology, and sociology of the rule of law has a lasting legacy. It becomes highly relevant in times when the rule of law is systematically misused or even abused by populist leaders and governments. In this respect, the European Union is an interesting case study-it is a supranational organization founded on the rule of law, which includes Member States with an established rule of law tradition as well as States where the rule of

Anna Śledzińska-Simon

anna.sledzinska-simon@uwr.edu.pl

1 Assistant Professor of Constitutional Law, Department of Law, Administration and Economy, University of Wrocław, Wrocław, Poland

2 Associate Professor, Eötvös Loránd University, Budapest; Visiting Faculty Member, Central European University (CEU), Budapest; and Visiting Professor, Goethe University, Frankfurt, Germany 
law is relatively new, while a systematic disregard of the rule of law in any Member State is likely to threaten the stability of the entire European integration project.

The diversity of legal traditions, conventions, and societies in the EU has always been a challenge to its unity. Currently, it also leads to a paradox - on the one hand, the European Union needs to respect the national constitutional traditions of the Member States, ${ }^{1}$ and on the other hand, it has to remain vigilant with regard to abuses of the rule of law. ${ }^{2}$ Therefore, it is pertinent to ask whether there is one definition of the rule of law within the EU that is common to all EU Member States, or whether the EU allows divergent understandings of the concept and recognizes that different institutional designs may serve the purpose of the rule of law equally well.

In this regard Martin Krygier's work is helpful in exploring the multiple dimensions of the rule of law conundrum, but also to provide legitimacy to legal actions aimed at resolving the current crisis in the EU. Specifically, the three questions he asks — why?, what?, and how? (Krygier 2001, p. 28)—should be revisited in order to address the point (teleos) of the rule of law, the conditions that the institutions need to fulfil to make this point, and institutional measures that help to meet these conditions in the particular circumstances of the EU as a whole and its Member States.

While the teleos of the rule of law is generally easy to establish, the "what" and "how" questions lend themselves to local solutions. Still, it is clear that certain local solutions should not be accepted in the EU as they thwart the realization of the common purpose (especially if they divert from the original design that was approved of in the process of EU accession ${ }^{3}$ ). The realization of the purpose of the rule of law is at risk when national measures generate a fear of oppression or provide room for an unpredictable exercise of power. Hence, in essence, the purpose of the rule of law is to reduce fear (distrust) and to facilitate cooperation (Krygier 2006, p. 134).

Although one universal, institution-based answer to what the rule of law is seems to be implausible (both in the EU and beyond), there are basic elements of the rule of law structure, or "anatomy" to use Kryger's words, that are required at the national level. Following this approach, the EU does not have to start with a list of norms, institutions, and practices related to the rule of law to be installed in the Member States, but only to check whether they serve the purpose of the rule of law.

Ultimately, the purpose of EU actions with regard to the rule of law is to guarantee the effectiveness of EU law against intimidation by the national authorities, the caprices and arbitrariness of decision-makers, unfair procedures, corruption, informal power structures, and the like. Notably, in order to tackle rule of law violations in the Member States the EU has an entire arsenal of means at its disposal (Pech and Kochenov 2019). However, we argue that legal actions seem to be the most adequate.

\footnotetext{
1 Article 4(2) of the Treaty of the European Union (TEU).

2 The rule of law as a common value is explicitly mentioned in Article 2 TEU.

3 Since 1993 the rule of law has been part of the Copenhagen (accession) criteria defining the eligibility of a country to join the European Union.
} 


\section{The EU's Rule of Law Toolkit}

The phenomenon of rule of law backsliding (Pech and Scheppele 2017, p. 10) received increased attention when a blatant disregard of rule of law standards became evident in two Member States-Hungary (in 2010) and Poland (in 2015). Although each case involving a rule of law violation is different, what distinguishes such cases from other breaches of Treaty law is that the government responsible for dismantling the rule of law does not acknowledge problematic legal measures or policies as a breach. Instead it is likely to justify such measures as part of its national constitutional identity (Śledzińska-Simon and Ziółkowski 2017).

The EU has two main options to address problems with the rule of law in the Member States-political and legal. The political response may trigger the Article 7 TEU mechanism, while legal action may take the form of infringement proceedings pursuant to Article 258 TFEU. Infringement proceedings are simultaneously narrower and broader than Article 7 procedures. While the former must involve an EU law element, the latter may also cover matters falling outside the scope of EU law. Yet, the infringement procedure may be employed to tackle any failure within EU law of whatever gravity, whereas the Article 7 TEU mechanism is there to address a "serious" or a "serious and persistent" breach of the values enshrined in Article 2 TEU, including the rule of law. Taking into account the nature of such a breach, the two actions appear to be complementary since "in the case of the infraction procedure, the failure is more limited and circumstantial, whereas in the context of Article 7 TEU, the breach becomes systematic" (Hillion 2016).

We claim that political and legal actions not only could, but should be initiated at the same time. While Article 7 TEU on its own may not be effective in halting rule of law violations, it may provide legitimacy for the Court of Justice when ruling on such cases (Buras and Knauch 2018). We see a great potential in applying infringement procedures against systemic violations of the rule of law to ensure respect for the common values enshrined in Article 2 TEU.

\section{Rule of Law Infringement Procedures}

We argue that there is a great potential in the infringement procedure to tackle rule of law issues in the Member States, provided that the following rules are applied.

First, the European Commission should call a spade a spade and explicitly recognize the rule of law problem. It should not misconstrue such cases as incidental breaches of EU law, but take into account the gravity of the harm and the consequences of the rule of law violations for the entire legal system.

Second, the European Commission should not waste time and postpone its legal actions, while a Member State openly violates the rule of law. Whereas dialogue and tolerance are European virtues, experience has taught us that there is no reason to engage in a lengthy discursive process with a government charged with rule of law backsliding. 
Third, the Court of Justice of the European Union (CJEU) should automatically prioritise and accelerate infringement cases involving a rule of law element. This proposition builds upon the pilot judgment procedure of the European Court of Human Rights. We argue that all infringement procedures in which the Commission invites the CJEU to deal with a systemic problem caused by a rule of law violation should be expedited to avoid more harm. Once an infringement case has an identifiable rule of law element, it should automatically be decided in accelerated proceedings.

Fourth, interim measures may be used to put an immediate end to rule of law violations that can culminate in grave and irreversible harm. We argue that even an accelerated process will often not be sufficiently expeditious to prevent a systemic violation of the rule of law. In cases where an infringement procedure is pending, the European Commission should request, if relevant, interim measures to be ordered by the CJEU, in line with the precautionary principle. In the past interim measures became very effective after the CJEU had decided that penalty payments would be imposed against the Member State in question if it failed to comply with the order both immediately and fully (C-441/17 Commission v Poland).

Fifth, a periodic review mechanism on democracy, the rule of law, and fundamental rights (the DRF monitoring and enforcement mechanism) should be established in the EU to allow a contextual analysis of the Members States' national laws and policies on the basis of a scientifically proven methodology, objective standards and equal treatment. It could signal to the Commission when to start rule of law infringement procedures or whether it is necessary to request interim measures. Furthermore, it could allow the EU to act promptly and to suspend the application of EU laws based on mutual recognition, and thus relieve the courts of this burden. It could further indicate when mutual trust can be re-established thereby removing this matter from the courts.

\section{Judicial Independence and the Rule of Law Anatomy in Commission v Poland}

In the recent case against Poland the Commission alleged that the lowering of the retirement age for Supreme Court judges from 70 to 65 without a meaningful transitional period and granting the President of Poland the discretion to extend the active judicial service of Supreme Court judges was a violation of EU law (C-619/18 $R$ Commission $v$ Poland). The legal claim was based on Article 19(1) TFEU and Article 47 of the Charter of Fundamental Rights. The Commission alleged that the new law concerning the Supreme Court was in breach of the principle of judicial independence and, in particular, the principle of the irremovability of judges, which form the core of the rule of law.

On 19 October 2018 the Court issued its (provisional) interim order. It mandated a retrospective suspension of the Act on the Supreme Court with regard to the First President of the Supreme Court as well as the forcibly retired judges of both the Supreme Court and the Supreme Administrative Court. This order was a special kind of order. First, it was issued to suspend a legislative act of a Member State, and 
not an act of the EU institutions. Second, contrary to the established case law, it was meant to restore the status of judges from before the infringement action was lodged (and a final decision of the Court rendered). Third, it was issued in an urgent procedure, which allows the President of the Court to grant the application of an interim measure before hearing the party concerned.

The interim measure had considerable domestic influence. On 21 November 2018 the Polish Parliament adopted amendments that restored the previous retirement age for active judges and declared that their service had not been interrupted. The law also removed the power of the President of the Republic to grant permission to continue judicial service after the judges in question had reached retirement age. These changes notwithstanding, the infringement proceedings against Poland continued before the Court because at the end of the period laid down in the reasoned opinion of the Commission, the impugned provisions were still in force.

According to the Commission, the concept of effective legal protection must be interpreted in connection with the right to an effective remedy. The Commission asserted that judicial independence, as an essential part of the fundamental right to a fair trial, is no longer guaranteed if a national measure affects that the independence of a national court. The requirement "concerns not only the way in which an individual case is conducted, but also the way in which the justice system is organised" (para. 36). The consequence of a national measure generally affecting the independence of the national courts is that an effective legal remedy is no longer guaranteed, inter alia when those courts interpret and apply EU law.

Although the organization of the justice system is beyond the EU's competence, the requirement of judicial independence is a key to provide effective legal protection in the areas covered by EU law. More specifically, the Court reiterated its position expressed in earlier case law, according to which the Member States shall comply with obligations stemming from EU law even if they exercise their exclusive competences. Therefore, the obligation to ensure effective legal protection in the fields covered by Union law entails the duty to preserve the independence of the Supreme Court, which is entrusted with the task of interpreting and applying EU law.

In this case, the rule of law was analysed in relation to the requirement of effective judicial protection. In this context, the Court recalled that the EU is based on mutual trust and the judicial system, involving special procedures (like the preliminary ruling procedure) to facilitate dialogue between the courts and, ultimately, to ensure the full effect and autonomy of EU law. These findings answer the "why" question as they explain the point of having the requirement of effective judicial protection.

The "what" question is answered by reference to the requirement of judicial independence that needs to be secured in any court or tribunal within the EU. Hence, the national provisions governing the composition, the organisational structure, and the working methods of the Supreme Court should ensure that it meets the independence requirement. That requirement is a basic element of the right to effective judicial protection and the fundamental right to a fair trial. In this regard, the Court is less concerned about the scope of application of the Charter of Fundamental Rights, but about the realization of the individual right to challenge the legality 
of any decision or other national measure concerning the application of an EU act as far as they are concerned (C-64/16 Associação Sindical dos Juízes Portugueses, and C-216/18 PPU Minister for Justice and Equality (Deficiencies in the system of justice)). At this point, the Court explained that the external aspect of judicial independence entails specific guarantees against any arbitrary removal from office. Yet, when referring to the principle of irremovability, the Court admitted that it may be subject to limitations provided that they are justified by a legitimate aim and are proportionate.

In this case, the Court did not determine the content of national norms but the basic conditions which need to be fulfilled to ensure judicial independence. The Court certainly did not refer to how the principle of irremovablity is best achieved and neither did it indicate institutional measures that best fit particular social circumstances. Instead it examined whether the national measure which lowered the retirement age for active judges could be justified. In this regard, the Court expressed doubts as to whether the measure had an objective justification. Contrary to the Polish government that claimed that the measure served the standardization of the retirement age and improved the age balance, the CJEU was left with an impression that it had been adopted in order to exclude a predetermined group of judges from the Supreme Court (para. 85). In addition, it also found that the chosen measure was not suitable to serve the declared purpose and was disproportionate (paras. 90-91).

The second challenge to the law was resolved on a slightly different ground. The Commission challenged the national law with regard to the power of the President of the Republic to extend the period of service for judges who reached the new retirement age. In this regard, the Court underlined that "it is for the Member States alone to decide whether or not they will authorise such an extension to the period of judicial activity beyond normal retirement age, the fact remains that, where those Member States choose such a mechanism, they are required to ensure that the conditions and the procedure to which such an extension is subject are not such as to undermine the principle of judicial independence." (para. 111). For the Court, the solution adopted in Poland gave rise to doubts as to "the imperviousness of the judges concerned to external factors and as to their neutrality with respect to any interests before them." (para. 118). As a result, the Court found that the Member State in question had failed to comply with the obligation to provide effective judicial protection with regard to both challenges.

\section{Conclusions}

A mature constitutional system, built on the principles of democracy, the rule of law, and fundamental rights, presupposes the existence of robust precautionary measures against anti-constitutional tendencies and forces. These are designed to protect democracy against a 'constitutional coup d'état', which may replace a constitutional government with an autocratic one. The blueprint for rule of law backsliding entails that election laws are curbed, constitutional courts are compromised, ordinary judges are unduly influenced, media pluralism is destroyed, participatory democracy 
is dismantled, civil society is harassed and several fundamental rights are denied. To prevent this from happening the European institutions need to make use of preventive tools because once a constitutional regime is compromised, the chances that it can be restored are slim.

Should judicial independence be under threat in some Member States, we might arrive at a situation where the EU harbours countries that would not qualify for EU membership if they applied today. In addition, as Kochenov and Bárd (2018) have demonstrated, basic EU principles, such as autonomy, primacy and mutual trust, will be jeopardised unless EU law embraces the rule of law as an institutional ideal and takes Article 2 TEU values to heart in the context of the day-to-day functioning of the Union.

When it comes to the actual assessment of the situation on the ground, we acknowledge that the rule of law can be attained via various paths, but there is general agreement on when its basic elements, such as the guarantees against the arbitrary removal of judges, are missing. Therefore, the EU does not need to determine the anatomy of national institutions, but it needs to remain vigilant with regard to such modifications that put at risk the effectiveness of EU law, and the judicial protection of individual rights in particular. This is essential both for the protection of the fundamental rights of individuals, but also for the protection of judges or other public officials as a special category of right-holders.

Open Access This article is distributed under the terms of the Creative Commons Attribution 4.0 International License (http://creativecommons.org/licenses/by/4.0/), which permits unrestricted use, distribution, and reproduction in any medium, provided you give appropriate credit to the original author(s) and the source, provide a link to the Creative Commons license, and indicate if changes were made.

\section{References}

Buras P, Knaus G (2018) Where the law ends. On the collapse of the rule of law in poland and what to do about it, IDEA FORUM, Policy Paper, May

Hillion C (2016) Overseeing the rule of law in the EU. In: Closa C, Kochenov D (eds) Reinforcing rule of law oversights in the EU. Cambridge University Press, Cambridge, pp 59-81

Kochenov D, Bárd P (2018) Rule of law crisis in the new member states of the EU: pitfalls of overemphasizing enforcement. RECONNECT, Working Paper No. 1, July

Krygier M (2001) Transitional questions about the rule of law: why, what, and how? part 1. East Central Europe 28:1-34

Krygier M (2006) The rule of law: an abuser's guide. In: Sajó A (ed) The dark side of fundamental rights. Eleven International Publishing, Hague, pp 129-161

Pech L, Kochenov D (2019) Strengthening the rule of law within the EU: diagnoses, recommendations, and what to avoid. RECONNECT, Policy brief, June

Pech L, Scheppele KL (2017) Illiberalism within: rule of law backsliding in the EU. Cambridge Yearbook of European Studies 19:3-47

Śledzińska-Simon A, Ziółkowski M (2017) Constitutional identity in Poland: Is the emperor putting on new clothes of sovereignty? In: van der Schyff G, Callies CH (eds) Constitutional identity in a Europe of multi-level constitutionalism. Cambridge University Press, Cambridge.

Publisher's Note Springer Nature remains neutral with regard to jurisdictional claims in published maps and institutional affiliations. 